\title{
LOOKING FOR THE BEST SLOGAN: AN ANALYSIS OF THE SLOGANS OF THE 2016 ROMANIAN PARLIAMENTARY CAMPAIGN
}

\author{
Brînduşa-Mariana Amălăncei \\ "Vasile Alecsandri" University of Bacau, \\ amalancei.brindusa@ub.ro \\ Cristina Cîrtiţă-Buzoianu \\ "Vasile Alecsandri" University of Bacău \\ buzoianu.cristina@ub.ro \\ Corina Daba-Buzoianu \\ National University of Political Studies and Public Administration (SNSPA), \\ Bucharest, Romania \\ corina.buzoianu@comunicare.ro
}

\begin{abstract}
The paper investigates the slogans released by political parties during the elections for the Romanian Parliament in 2016, by addressing the way they have been perceived by both political analysts and students enrolled in communication programs. We aim to see how two different target audience evaluate the slogans and how they refer to them. Also, we are interested to see what the students remember about the slogans after six months after the end of the campaign, in order to explore if their memories about the slogans had any connection with the political analysts comments made during the elections.
\end{abstract}

\section{Keywords}

communication analysis; Romanian parliamentary campaign; young generation's interest for slogans; image within slogans

\section{JEL Classification}

M37

A large body of research deals with the image promoted by the candidates and political parties during electoral campaigns, aiming to understand the way politicians used the different topics and approached specific issues in order to gain votes. This has been dealt with by using both quantitative and qualitative studies, in order to analyze the messages and the candidates' representation from different perspectives. Although political campaigns have significantly changed along the years, there is still evidence that they have an important influence in the public's decision (Seidman, 2008), as in some cases, posters, banners and slogans used during a campaign for the elections have turned out to make a difference for some of the candidates. A complex set of factors based on message, picture, colours, background, set up and several others is to be considered to have an impact on the public when making a decision, although the process itself is much larger and with many other important triggers.

Among the above mentioned, slogans are very important as they transmit a very specific idea and they have a role in shaping the candidate's image. They are expected to enhance brand awareness and to create and support the image (Kohli, 2004). As a familiar and current formula (Lee, 2014), short, easy to remember (Jaubert, 1985) and to recognize, a slogan draws attention and is meant to incite to action, both through its style and its passionate or rational self-justification it involves (Reboul, 1975, 42; 
Garric, 1996, 25). Slogans are ephemeral, but some of them remain in the collective memory for a long time, sometimes entering in full or partially in everyday language. As widely expressed in the literature on the field, slogans are to be used to only for awareness, but also for creating a positive image, by telling in few words a story (Kohli, 2007).

Depending on the field in which they appear, slogans are divided into political, social and advertising. Scholars have not reached a consensus regarding the typology of slogans and therefore some features remain unclear. Some scholars note that the advertising and political slogans have too much in common in order to able to consider two different categories (Lee, 2014, 80), while others vividly point out that there are many aspects to take into consideration and that political slogans have totally different aims and mechanism (Anton, 2006, 24).

The political meaning of the term of advertising slogan dates back to 1932, being a political propaganda formula. Slogans are part of the category of persuasive political messages, along with the messages from the poll programs and press conferences organized by the politicians, the speeches at the party meetings, the speeches held at election rallies and other political gatherings, posters, advertisements, press releases, interviews and appearances in televised debates (Fârte, 2004-2005, 115).

\section{Successful political slogans}

As widely mentioned in the existent literature on political communication campaigns, creating a slogan for the political campaign is the result of a team brainstorming, but only one person has the task to reflect on the various proposed variants. Slogans should have strong names and call to action. Also, slogans should be consistent with the overall communication campaign and should be clear enough to be easy to understand and remember. It is recommended that a slogan be concise, short and accessible in terms of the vocabulary used, and the adjectives it contains reflect the ideological line of the campaign. A good slogan must also be striking and should remain for a long time in the collective memory (Joseph, 2012). An important element is the authenticity of the slogan and the perfect link with the image that the political actor already has. Significant discrepancies between the slogan and the overall image of the candidate may lead to a fail (Teodorescu, 2001, 123).

In order to succeed, a slogan may be confronted with the following conditions: the condition of a positive form, the condition of meaning univocity, and the condition of common sense (Fârte, 2004-2005, 118). Thus, the negative form of a slogan may be a disadvantage for a candidate in motivating electors to vote. Finally, it is recommended that the desire to be striking through a slogan has nothing to do with the insoluble formulas, which transgress the framework of the political discourse and which could undermine the sensitivity of certain electors (Fârte, 2004-2005). Scholars dealing with political campaigns slogans mention that there are several elements that differentiate them among other types of slogans, like advertising ones (Sălăvăstru, 1999, 292-305). As they point out, political slogans are dissembled language, as it always says much more. As Sălăvăstru argues, an excellent political slogan should always consider the fact that the simplicity is one of the most important features. Due to the fact that it aims to reach large audiences and groups of people, political slogans can't talk about programs, platforms and projects. Instead, they should tell a story and call to action, talk about a dream and share the dream with the public. By making visible the candidate's perspective and way of thinking, the slogans manage to state the position towards the other political opponents. A powerful political slogan needs to include the emotions of the public, as the public should like it and feel it says something about them or about their way of thinking (Stoiciu, 2000; Magnes, Teyssier d'Orfeuil, 2013; Silnicki, 2016). 


\section{Image within text and slogans}

In a certain way, by investigating how different publics analyse and interpret the slogans, our papers deals also with the image within text. More precisely, it deals with the image within the slogans used by the candidates in the elections for the Romanian Parliament in 2016. In doing this, it looks at the representation constructed through text, by having in mind the philosophical relation image-object-subject, in which image stands for representation (Mitchell, 2005), as it was previously explored in the analysis of the 2014 elections for the European Parliament in Romania (Oprea \& Daba-Buzoianu, 2015). Thus, in the image making process, the relation object-subject is to be seen as a constantly changing phenomenon and also as a process in which the meaning of the object is constructed throughout communication. Thus, the meaning of the object is created by the subject and it depends on a variety of elements, widely studied in the literature on the field. For the current study, the focus is not on these elements, although it will be explored in further studies, but on the perception and interpretation given by the participants to the slogan released by the candidates during the 2016 elections for the Romanian Parliament.

As Hall (2005) extensively argues, the key element in the process of imaging is the production of meaning, as the message, together with all the other elements in a poster, generate an image. From this point of view, the image to be explored within slogans is the representational component of the message, and not the image as a mental representation. This distinction is quite important as it underlines the conceptual framework of the image, seen in the current paper as the representation transmitted through the messages and deciphered by the public. As the current study is based on a small mixed-methods quantitative analysis, an inquiry about the image of the candidates will not be possible. Instead, if we were to consider the complex process of image, we could easily say that the paper refers only to its first stages and explores the representation transmitted to the public.

\section{The context of the 2016 parliamentary campaign}

The year 2016 has brought a series of interesting and unexpected events both in Romania and other countries. The very surprising Brexit and Trump's election as a president of the USA, together with the political situation in the region (Republic of Moldova and Bulgaria) are worth mentioning examples in this respect. Romania was also in line with these tendencies, as 2016 was the first year in the countries' history when the government was technocrat. The technocrat prime minister, Dacian Cioloș, was vividly supported by social media users as was considered the best prime minister by the young adults. Unlike other campaigns for the Romanian Parliament, the 2016 campaign was not dominated by powerful political leaders, but rather by the political parties themselves, with one exception - the technocrat prime minister in office Dacian Cioloș, supported by the National Liberal Party. As some authors mention, it is quite clear that the 2016 elections meant a vote for the party and not a vote for the candidate, where the strong and well-organized parties had the first chance (Grecu, 2017, 135).

In Romania, the 2016 parliamentary elections were dominated by the legislative changes (Law 113/2015; Law 78/2016) regarding the electoral system, replacing the mixed, controversial and non-functional uninominal vote with the classical vote based on a list and proportional representation. Thus, the discussion about the party supremacy imposing the order of politicians on the list was again brought forward. There were differences from the previous campaigns also regarding the large-scale street banner which was banned, as well as constraints on the funding of political parties (state budget campaign financing, clear specifications for sponsorship and donations). 


\section{Method}

The aim of the paper was to explore the image within the slogans by looking at the way they have been perceived by two audiences: political analysts, commenting on online platforms, and students enrolled in a communication academic program. Our intention was to investigate and compare how the two public categories refer to the political slogans. A mixed-methods approach was used: content analysis of the comments posted by the political analysts in two online media platforms: www.agerpres.ro and www.jurnalul.ro and a small survey based on questionnaire with students enrolled in the communication program at University 'Vasile Alecsandri' of Bacau.

The content analysis was conducted on two online media platforms (www.agerpres.ro; www.jurnalul.ro) in November-December 2016 and aimed to study how the political analysis referred to the political slogans and how they analyzed them. The political analysts posting comments on the slogans of the political candidates are: Barbu Mateescu, Radu Magdin, Cristian Pîrvulescu, Marius Pieleanu, Alfred Bulai, Bogdan Ficeac and Antonio Momoc. Six of them posted on www.agerpres.ro and one on www.jurnalul.ro. The content analysis grid main elements were: topics of the message, the memorability feature of the slogan and the link with the political party and ideology.

The questionnaire $(n=40)$ used for the study was applied in May 2017, 6 months after the elections. The students participating to the survey are enrolled in the second year of the communication program at University 'Vasile Alecsandri' of Bacau. From a total of 55 students present in class, only 40 agreed to participate to the study. The questionnaire was self-administrated. The participants were aged between 20 and 30 . Before this, details and the survey were provided to the students. The aim of the study was to investigate the way the slogans were perceived by the participating students, how they were interpreted by them and in what way they considered them successful. We also were interested to see in what way the students taking part to our study were interested in the political slogans and in what way they considered them in line with the image of the candidate. The questionnaire was designed to offer insights about the slogan awareness, as students were asked to match the political slogans with the parties. The low number of participants in the survey is due to the fact that this is a pilot study, to be followed by a larger quantitative one.

\section{Results and discussion}

The content analysis of texts posted by the political analysts revealed a general discontent regarding the communication campaigns of the Romanian candidates. When characterizing the political slogans, the analysts use the labels: uninspired, lacking identity, tautological, monotonous, which may indicate that they were not designed by communication specialists. In most of their comments, the analysts disagreed with the fact that the main topic chosen by the political actors engaged in the elections was patriotism. The high recurrence of the words Romanian and Romania was considered inappropriate for a political campaign in an EU member state. An interesting critique was brought up, as some would expect to see a link between the slogans and the political identity and ideology of the party. The absence of this connection or a poor one would lead, say the analysts, to confusion of the public. Still, the comments posted by the political analysts do not mention in what way these connections should have been done and in what way would the public be interested to receive slogans comprising ideology messages.

According to the analyst Radu Magdin, the theme Romania was used by the majority of the parties, but in many different ways. As the analyst mentions, Romania was used in association with leadership, protection, and intelligence. Other analysts discuss 
about the emotions that slogans should trigger and state that the ones used by PSD and PNL do not stir any emotion. The Dare to believe in Romania may trigger a sense of insecurity, while Romania ahead and We are Romanians are truisms. Another critique is linked to the fact the ALDE's slogan We give Romania back to Romanians has nothing to do with the party's political identity nor with its very recent history. The PER slogan We protect Romania is according to Bogdan Ficeac in the tone of the ecological message, but it lacks imagination. Moreover, the party failed in the postDecember history to occupy a well-defined place on the political scene, so the idea itself does not convey a credible message. The UDMR slogan, Transylvania, the future for all of $u s$, is addressed only to a certain electoral segment, the essence of the message being the requirement of territorial autonomy, which is in full agreement with their political program. PMP's slogan Fight for Romania is criticised due to the fact that it was previously used in the elections for the EU Parliament.

The analysts considered that the most successful slogans are: You finally have somebody, slogan belonging to USR, which is better thought to be constructed in terms of novelty (new party, new politicians), but also easier to remember. Another positive example is Be smart, vote for Romania launched by PRM, which, by using the English word smart, tries to attract the younger segment, although it may contradict the party's traditional target audience.

In a very interesting way, some of the political analysts tried to evaluate the slogans with a check list, with elements wide spread in both the literature and in the professional activity of political consultants. Thus, they consider that most of the slogans failed and were inefficient as were not easy-to-remember, did not call to action and did not consider properly the public segmentation. Moreover, as the political analysts mention, this seems to be one of the most important problems of the slogans released by the candidates: addressing everyone and ignoring the core target. By doing this, the messages seem identical in terms of construction, but also from the point of view of the proposed meaning or vision, which either makes no sense or does not bring anything new.

As the political analysts mention, the slogans were built around the idea of patriotism, and in many ways are very similar. Although the following slogans: Dare the believe in Romania, Romania ahead, We give Romania back to Romanians, Fight to Romania, We protect Romania are released by different parties, with different identities and ideologies, the slogans have no distinct features and are very difficult to link to a certain political party. The labels similar and no imagination have been used by the analysts to describe the slogans. Due to the fact that they all revolve around the same key concept and do not coagulate a memorable force-idea, capable of creating persuasive effects in the collective mentality, there is no hope for call to action. Also, the high recurrence of the patriotism topic is considered somehow surprising due to the political context, that does not justify the need for a patriotic message.

The current study gathered data from a small survey based on a questionnaire aiming to investigate how students studying communication in their undergraduate program. In line with the comments of the political analysts, 24 of the participants in our quantitative study say that slogans are very important in elections and have a significant role for getting people to vote for you. The students mention that this importance is linked to the fact that a slogan represents the essence of the communication campaign during the elections. 16 of the participants answered that slogans are relevant only if they are complementary with other messages and with the overall image of the candidates and parties.

The students participating to our study consider that the slogans should be/have: memorable (24), strong message (14), commercial character (2), while none consider that they should have simplicity and novelty as a feature. Still, the majority of the participants consider that the slogans are not inspiring at all. Very interesting is the 
fact that 30 of the students remembered that most of the slogans in the elections were built around the theme of change, while only 5 said that they were focused on Romania and Romanians. This is very much not in line with the comments of the political analysts. Thus, although the idea of change is not very visible in the slogans, the students answering our questionnaire remembered it instead of the patriotic recurrent topic, vividly discussed by the political analysts.

When asked about the most successful and powerful slogans, the participants choose for evaluation force message criteria and include Dare to believe in Romania and Fight for Romania, fact that is contradictory to the evaluation of the political analysts. The slogan You finally have somebody to vote for was considered successful for its novelty, while Protect Romania and Be smart, vote for Romania conveyed the idea of security, We are Romanians and Romania ahead comprise the idea of continuity and We give Romania back to Romanians referred to the historical past. Thus, the participants evaluated as best-designed slogans: Dare to believe in Romania and $\mathrm{Be}$ smart, vote for Romania, followed by We give Romania back to Romanians. The slogan Be smart, vote for Romania, in the case which the word smart was the English word, was considered very appropriate addressing the young public (Figure 1).

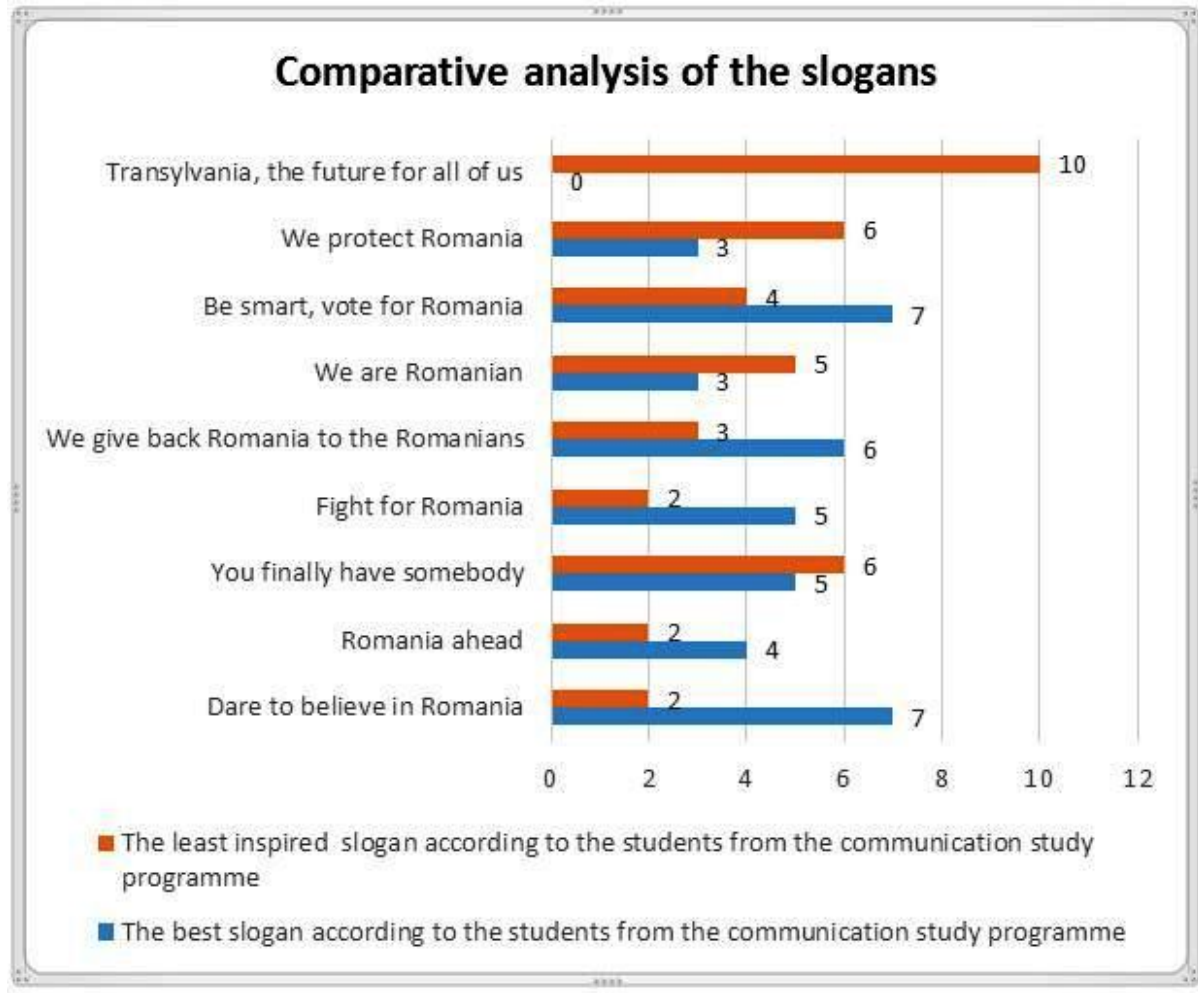

Figure 1

Among the least successful slogans, the students ticked Transylvania, the future for all of us with 10 answers, You finally have somebody and Protect Romania with 6 answers each, as well as We are Romanians, with 5 answers. The large number of references obtained by the UDMR slogan is justified by the fact that the message does not concern the whole electorate, but only the ethnic minority traditionally voting for this party. The USR slogan brings an element of novelty by identifying itself with the people that the party proposes on the lists and who are not politicians, but professionals, scientists who are trying to rally the undecided electorate. 
When asked if they are influenced by the slogan when voting for a party or candidate, 20 respondents think the slogan is important, compared to 10 of them who believe it is an essential element. Although, previously, for the question: How important is the slogan in the election campaign? all participants considered it very important or quite important, only half of the total have admitted that the slogan has a direct influence on the vote. The audience is able to evaluate the role and importance of the campaign slogan in terms of communication, but it is not the defining element that inclines the vote balance in a campaign.

The students were also asked to associate the slogan with the party that used it in order to determine which of the 9 slogans was remembered and connected to the messages that the political formations had transmitted. It appears that among the most well-known slogans is You finally have somebody (USR) with 21 answers, Dare to believe in Romania (PSD) with 16, and Transylvania, the future for all of us (UDMR) with 12 answers. The slogans which were less recognized by the students are $B e$ smart, vote for Romania (PRM), with 0 answers, We give Romania back to the Romanians (ALDE) with 3 answers, and Fight for Romania (PMP) with 5 answers.

The ranking of the USR slogan on the first position, but also the most remembered and associated with the party that promoted it, show that the targeted segment was the young electorate. The recognition of the UDMR slogan is due to the word Transylvania which is found within and immediately determines the connection with the political formation. The slogan Be smart, vote for Romania, of the PRM, was confused with We are Romanians, of the PRU, as a result of the message. Thus, although it was appreciated from the point of view of the communicative construction, there was, however, a mismatch with the ideology promoted by the party. The same thing happened with the ALDE slogan We give Romania back to the Romanians, which was confused with those of the PNL and PRU. We can also see that the slogans of the large parties, such as the PSD and the PNL, were well represented, while the message of the small parties did not catch the attention of the young audience. The exception was the USR slogan, which managed to rally the young, but also to remain memorable after the end of the electoral campaign.

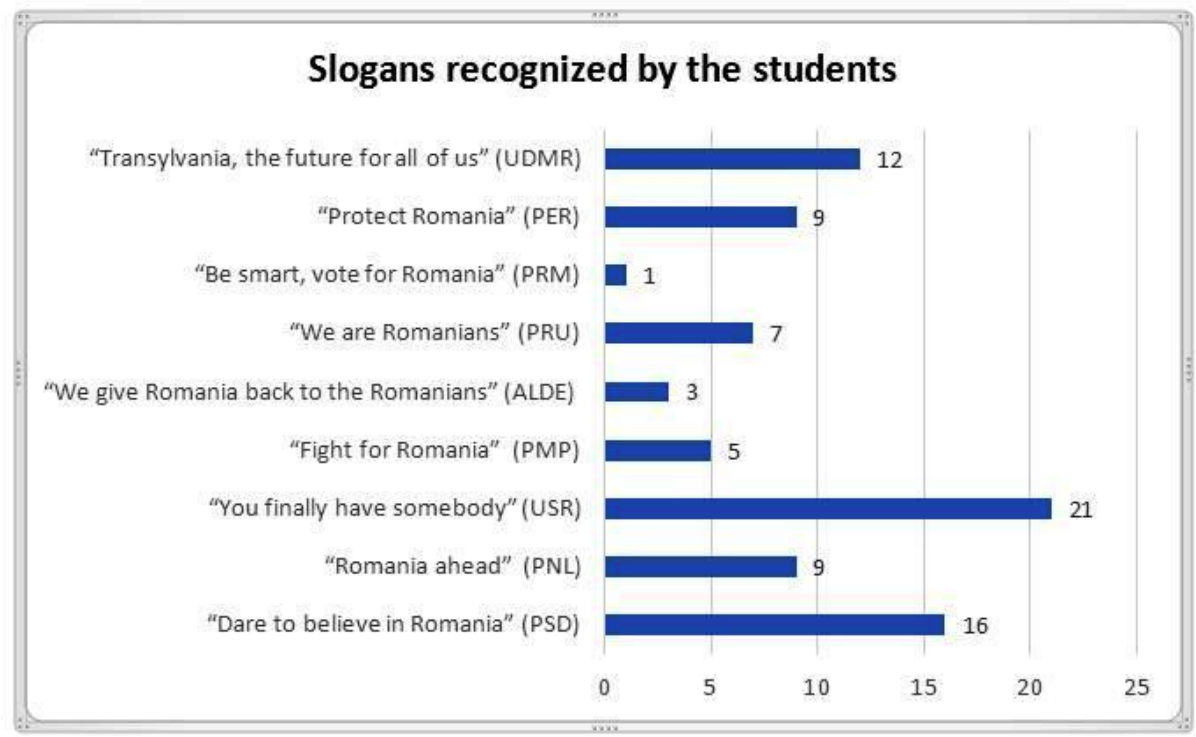

Figure 2 
Regarding the question Do you think it is good to have a similarity between slogans? a number of 30 students attending the study believe that it is a mistake, because there is no difference between them, while 10 consider that it is a good idea to create a deliberate ambiguity.

Through our approach, we aimed to investigate how the political slogans have been interpreted and remembered among the students from the communication study programme. The analysis shows that they are interested in the messages sent by the political parties and the way in which they are conceived and promoted at the level of the young electorate, as well as in connection with the party's identity. There were slogans that were appreciated, but which, from the students' perspective, did not suit the political formations, creating confusion among the audience, namely the PRM slogan or the ALDE slogan. At the same time, the thematic similarity that existed between the slogans created confusion, both at the representative level and in terms of being topical in the political context in which we report. Although there was an interest in the slogans promoted during the campaign, they were not considered to be defining elements in determining the voting option for a particular party, even though most subjects admit that they do play an important role in promoting parties and candidates.

\section{Conclusion}

Although the current research is based on a small scale study, it reveals some interesting aspects regarding the way the public refers to the political slogans. First, there are similarities between the existent literature on the field regarding slogans and the opinions expressed by the political analysists and the participants in our survey. In line with the previous studies, it is acknowledged that the slogans should be simple, memorable and adapted to the target audience of the political candidate. Still, as expressed by some of the political analysis, the slogans are expected to refer to the political program, although it is widely accepted that this would lead to uninspiring message. Secondly, our study pointed out that even though the political analysts underlined that the slogans were too much focused on patriotism and used too many times the words Romania and Romanians, six months after the elections ended the students remembered that the main topic of the slogans was change.

\section{References}

Anton, M. (2006), Le discours politique et la manipulation du récepteur, ANADISS, $17-51$

Fârte, Gh.-I. (2004-2005), Comunicarea politică: aspecte generale şi ipostaze actuale (in English Political communication: general issues and current hypostases), Argumentum. Journal of the Seminar of Discursive Logic, Argumentation Theory and Rhetoric, 3, 101-146.

Garric, N. (1996), Étude des structures linguistico-discursives du slogan publicitaire: activité et modes de quantification, Diss, Paris 3.

Grecu, F. (2016-2017), Alegeri parlamentare 2016: Proporţionalitate, finanţare, scrutin de listă, voturi şi mandate parlamentare (in English Parliamentary Elections 2016: Proportionality, funding, list scrutiny, votes and parliamentary mandates), POLIS, Journal of Political Science, vol. V, no.1(15), 129-144.

Hall, S. (2005), Representation, London, Thousand Oaks \& New Delhi, Sage Publications.

Jaubert, M.J. (1985), Slogan, mon amour, Paris, Bernard Barrault. 
Joseph, M. (2012, February 23), Comment se construit un slogan de campagne. Le Figaro. available at http://elections.lefigaro.fr/presidentielle2012/2012/02/23/01039-20120223ARTFIG00739-comment-se-construit-unslogan-de-campagne.php.

Kohli, C., Leuthesser, L., \& Suri, R. (2007), Got slogan? Guidelines for creating effective slogans, Business Horizons, 50(5), 415-422.

Lee, M. C.-H. (2014), Le slogan publicitaire, dynamique linguistique et vitalité sociale: la construction d'une esthétique sociale à travers la communication publicitaire, (Doctoral dissertation, Université Paul Valéry-Montpellier III).

Mitchell, W.T.J. (2005), What do pictures want? The lives and loves of images, Chicago, The University of Chicago Press.

Muraru, A. (2016-2017), Alegerile generale pentru Parlamentul României din 2016 reflectate în presa internaţională. Teme, analize, interpretări I (in English General Elections for the Romanian Parliament in 2016 Reflected in the international press. Themes, analyzes, interpretations I), POLIS, Journal of Political Science, vol. V, no.1(15), 61-99.

Oprea, D.-A., Daba-Buzoianu, C. (2015), Thèmes Européens et Représentations de l'Union Européenne: Les Affiches de la Campagne pour les élections européennes 2014, Journal of Media Research, 8(3), 63-76.

Reboul, O. (1975), Le slogan, Paris, P.U.F.

Sălăvăstru, C. (1999), Discursul puterii (in English The Power Discourse), Iaşi, Institutul European.

Seidman, S. A. (2008), Posters, propaganda, and persuasion in election campaigns around the world and through history, Peter Lang.

Silnicki, F. (2016, April 26), Slogans politiques: une communication souvent maladroite, Lafrenchcom.fr.

Teodorescu, B. (ed.) (2001), Marketing politic şi electoral (in English Political and electoral marketing), Bucharest, Comunicare.ro.

Stoiciu, A. (2000), Comunicarea politică - cum se vând idei şi oameni (in English Political Communication - How to sell ideas and people), Bucharest, Humanitas.

Teyssier d'Orfeuil, L., Magnes, J.-P. (2013), La méthode Coué pour les Nuls, Paris, Éditions First-Gründ.

Thoveron, G. (1996), Comunicarea politică azi (Political Communication Today), Bucharest, Antet.

Web resources:

http://www.agerpres.ro

http://www.jurnalul.ro 